\title{
Politik Hukum Pemberhentian (Pemakzulan) Presiden dan/atau Wakil Presiden di Indonesia dalam Prespektif Negara Hukum dan Demokrasi
}

\section{Muhamad Aksan Akbar \\ Fakultas Hukum Universitas Sembilanbelas November, Kolaka, Indonesia \\ *E-mail: akbaraksan53@gmail.com}

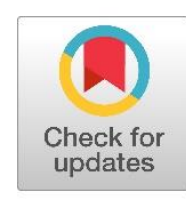

Dikirim: 04/04/2020

\begin{tabular}{l}
\hline Info Artikel \\
Keywords: \\
Politics of law; \\
Termination President \\
and / or Vice \\
President; State Law \\
and Democracy.
\end{tabular}

Kata Kunci:

Politik Hukum;

Pemberhentian

Presiden dan/atau

Wakil Presiden;

Negara Hukum dan

Demokrasi.

DOI:

10.47268/sasi.v26i3.276

\begin{abstract}
This study aims to determine the legal politics of dismissing the President and / or Vice President in Indonesia. The research method used normative research with a statute approach and a conceptual approach and analyzed descriptive qualitative. The results show that the dismissal of the President and / or Vice President in Indonesia is based on an understanding of a democratic state and an understanding of the rule of law. The application of the concept of a democratic state is carried out through a prior statement of opinion by the DPR and dismissal by the MPR. Meanwhile, the application of the rule of law is carried out through a legal process (forum previlegiatum), namely through examination of trials and decisions in the Constitutional Court. The choice of law is intended to strengthen the presidential system which adheres to the fixed term principle of the position of President and / or Vice President and to ensure the implementation of a stable state government.
\end{abstract}

Direvisi: 02/07/2020

Dipublikasi: 03/09/2020

\footnotetext{
Abstrak

Penelitian ini bertujuan untuk mengetahui politik hukum pemberhentian Presiden dan/atau Wakil Presiden di Indonesia. Metode penelitian menggunakan penelitian normatif dengan pendekatan perundangundangan (statute approach) dan pendekatan konseptual (conceptual approach) serta dianalisis secara deskriptif kualitatif. Hasil penelitian menunjukan bahwa pemberhentian Presiden dan/atau Wakil Presiden di Indonesia berpijak pada paham negara demokrasi dan paham negara hukum. Penerapan paham negara demokrasi dilakukan melalui pernyataan pendapat terlebih dahulu oleh DPR dan pemberhentian oleh MPR. Sedangkan penerapan paham negara hukum dilakukan melalui proses hukum (forum previlegiatum), yaitu melalui pemeriksaan persidangan dan putusan di Mahkamah Konstitusi. Pilihan hukum tersebut dimaksudkan untuk memperkuat sistem presidensial yang menganut prinsip fix term jabatan Presiden dan/atau Wakil Presiden dan untuk menjamin terselenggaranya pemerintahan negara yang stabil.
} 


\section{A. PENDAHULUAN}

Negara Indonesia adalah Negara Hukun (rechstaat) bukan Negara Kekuasaan (machstaat), dengan demikian, negara wajib menjunjung supremasi hukum (supremacy of the law) sebagai salah satu sendi politik bernegara, namun prinsip negara hukum tersebut belum sepenuhnya dijalankan dalam kehidupan berbangsa dan bernegara saat ini. Kenyataan menunjukan bahwa hukum terkadang justru dikalahkan oleh kekuatan-kekuatan lain, misalnya kekuatan politik, dalam sistem ketatanegaraan Indonesia Presiden memiliki kekuasaan yang sangat luas dan tidak dijelaskan secara terperinci dalam Undang-Undang Dasar Negara Republik Indonesia Tahun 1945. Untuk mengimbangi kekuasaan Presiden dan/atau Wakil Presiden tersebut maka diadakan suatu mekanisme pengawasan yang bisa berujung pada pemberhentian Presiden dan/atau Wakil Presiden. ${ }^{1}$

Berdasarkan sejarah ketatanegaraan Indonesia, tercatat telah empat kali mengalami pergantian Presiden sebelum masa jabatannya berakhir yaitu : Pertama, Presiden Soekarno diberhentikan melalui Ketetapan MPRS Nomor XXXIII/MPRS/1967 tentang Pencabutan Kekuasaan Pemerintahan Negara Presiden Soekarno; Kedua, Presiden Soeharto 'berhenti' setelah Ketua MPR/DPR mengumumkan permintaan MPR, agar Soeharto mengundurkan diri menyusul desakan demonstrasi mahasiswa dan elemen masyarakat lainnya pada tanggal 21 Mei 1998; Ketiga, Presiden B.J. Habibie berhenti setelah MPR menolak pertanggungjawaban pada Sidang Istimewa MPR tahun 1999, dan keempat, Presiden K.H. Abdurrahman Wahid diberhentikan oleh MPR melalui Ketetapan MPR Nomor II/MPR/2001 tentang Pertanggungjawaban Presiden Republik Indonesia K.H. Abdurrahman Wahid, karena tidak hadir dan menolak memberikan pertanggungjawaban dalam sidang istimewa MPR tahun 2001, dinilai terlibat dalam kasus penyelewengan dana bulog (Bulogate) dan dana bantuan dari Sultan Brunei Darussalam (Bruneigate) serta menerbitkan Maklumat Presiden RI tanggal 23 Juli Tahun 2001. ${ }^{2}$

Salah satu faktor ketidakstabilan posisi Presiden tersebut adalah karena UUD 1945 sebelum perubahan, tidak memuat aturan terperinci tentang pemakzulan Presiden, baik alasan maupun prosedurnya. Satu-satunya ketentuan dalam Undang-Undang Dasar 1945 sebelum perubahan, yang secara implisit mengatur kemungkinan pemakzulan Presiden adalah Pasal 8 Undang-Undang Dasar 1945 yang menyatakan: "jika Presiden mengkat, berhenti atau tidak dapat melakukan kewajibannya dalam masa jabatannya ia diganti oleh Wakil Presiden sampai habis masa jabatannya". Penjelasan Undang-Undang Dasar 1945 angka VII alinea ketiga, menyatakan: "jika Dewan menganggap bahwa Presiden sungguh melanggar haluan negara yang telah ditetapkan oleh Undang-Undang Dasar atau oleh Majelis Permusyawaratan Rakyat, maka Majelis itu dapat diundang untuk persidangan istimewa agar supaya bisa meminta pertanggungan jawab Presiden ". ${ }^{3}$ Ketentuan lebih lanjut mengenai pelaksanaan sidang istimewa ini diatur dalam Ketetapan Majelis Permusyawaratan Rakyat Nomor III tahun 1978 Jo. Ketetapan Majelis Permusyawaratan Rakyat No. 7 Tahun $1973 .{ }^{4}$ Adapun pengaturan tentang alasan pemberhentian Presiden

1 Sulistiani, A. (2018). "Impeachment Presiden (Studi Perbandingan Ketatanegaraan Indonesia dan Ketatanegaraan Islam)". Jurnal Al-Dastur, 1 (1) : 18-36 DOI : 10.30863/JAD.V1i1.348, h. 19

${ }^{2}$ Nazriyah, R. (2007). MPR RI Kajian terhadap Produk Hukum dan Prospek di Masa Depan. Cetakan Kedua, Yogyakarta: FH UII Press, h. 165-166. Sebagaimana dikutip oleh Mulyanti, D. (2018). "Mekanisme Pemberhentian Presiden dalam Sistem Pemerintahan Presidensial di Indonesia (Tinjauan Perbandingan Hukum di Negara Amerika Serikat, Filipina dan Sudan)". Jurnal Ilmiah Galuh Justisi, 6 (2) : 195-209 DOI : http://dx.dio.org/1025157/jigj.v6i2.1714, h.196.

3 Zoelva, H. (2014). Impeachment Presiden: Alasan Tindak Pidana Pemberhentian Presiden Menurut UUD 1945. Jakarta: Konstitusi Press, h.3.

4 Ibid., h. 4 
dan/atau Wakil Presiden setelah perubahan UUD NRI Tahun 1945 diatur dalam Pasal 7A yang menyatakan: "Presiden dan/atau Wakil Presiden dapat diberhentikan dalam masa jabatannya oleh Majelis Permusyawaratan Rakyat atas usul Dewan Perwakilan Rakyat, baik apabila terbukti telah melakukan pelanggaran hukum berupa penghianatan terhadap negara, korupsi, penyuapan, tindak pidana berat lainnya, atau perbuatan tercela maupun apabila terbukti tidak lagi memenuhi syarat sebagai Presiden dan/atau Wakil Presiden". Sedangkan ketentuan yang mengatur mekanisme pemberhentian Presiden dan/atau Wakil Presiden dalam masa jabatan diatur dalam Pasal 7B UUD NRI Tahun 1945 yang pelaksanaannya dilakukan oleh tiga lembaga negara yakni DPR, MK, dan MPR ${ }^{5}$.

Analisis alasan dan mekanisme pemberhentian Presiden dan/atau Wakil Presiden dalam masa jabatannya sebagaimana diatur dalam ketentuan Pasal 7A dan Pasal 7B UUD NRI Tahun 1945. MPR dapat memberhentikan Presiden dan/atau Wakil Presiden dalam masa jabatannya dengan alasan tertentu yang disebutkan secara limitatif dalam UUD 1945. Jika Mahkamah Konstitusi memutuskan membenarkan pendapat DPR bahwa Presiden dan/atau Wakil Presiden terbukti melakukan pelanggaran hukum dan konstitusi, maka MPR secara politik dapat memutuskan memberhentikan ataupun menolak untuk memberhentikan Presiden dan/atau Wakil Presiden dalam masa jabatannya. Dalam konteks negara hukum (rechtstaat) apakah keputusan politik MPR tidak memberhentikan Presiden dan/atau Wakil Presiden dapat diartikan bertentangan dengan prinsip supremasi hukum (supremacy of law) yang dikenal dalam Hukum Tata Negara dan bagaimana pertanggunjawaban Presiden dan/atau Wakil Presiden di hadapan hukum jika kemudian tidak diberhentikan oleh MPR. Berdasarkan uraian tersebut, masalah yang akan diteliti dalam penelitian ini, dirumuskan sebagai berikut: Apa alasan-alasan yang digunakan untuk memberhentikan Presiden dan/atau Wakil Presiden menurut UUD NRI Tahun 1945; Bagaimana mekanisme pemberhentian Presiden dan/atau Wakil Presiden menurut UUD NRI Tahun 1945; Bagaimana politik hukum pemberhentian Presiden dan/atau Wakil Presiden dalam prespektif negara hukum dan demokrasi.

\section{B. METODE PENELITIAN}

Penelitian ini merupakan penelitian hukum normatif, oleh karena itu sumber datanya menggunakan data sekunder berupa bahan hukum primer, bahan hukum sekunder dan bahan hukum tersier. Pendekatan yang digunakan dalam penelitian ini adalah pendekatan perundang-undangan (statue approach) dan pendekatan konseptual (conceptual approach). Data yang terkumpul, baik bahan hukum primer, sekunder, dan tersier dianalisis dengan menggunakan instrumen teori atau konsep untuk membahas atau memberikan jawaban terhadap masalah penelitian ini. Analisis data dilakukan dengan analisis kualitatif dan hasilnya dipaparkan dalam bentuk deskriptif.

\section{PEMBAHASAN}

\section{Alasan Pemberhentian Presiden dan/atau Wakil Presiden}

Sebelum terjadinya perubahan terhadap UUD NRI Tahun 1945, Presiden dapat diberhentikan dengan alasan-alasan yang bersifat politik, bukan yuridis karena tidak melibatkan lembaga peradilan untuk menguji secara yuridis kebenaran atas perbuatan yang

5 Sekretaris Jenderal MPR RI. (2011). Panduan Pemasyarakatan Undang-Undang Dasar Negara Republik Indonesia Tahun 1945 dan Ketetapan Majelis Permusyawaratan Rakyat. Jakarta: Sekretariat Jenderal MPR RI, h.91. 
dituduhkan tersebut. Oleh karena itu, hasil perubahan ketiga dalam Undang-Undang Dasar Negara Republik Indonesia Tahun 1945 memuat ketentuan pemberhentian Presiden dan/atau Wakil Presiden dalam masa jabatannya yang semata-mata didasarkan pada alasan-alasan bersifat yuridis dan hanya mengacu pada ketentuan normatif limitatif yang disebutkan dalam konstitusi. ${ }^{6}$ Undang-Undang Dasar 1945 Pasal 7A menentukan bahwa Presiden dan/atau Wakil Presiden dapat diberhentikan dalam masa jabatannya oleh MPR atas usul DPR baik apabila terbukti telah melakukan pelanggaran hukum berupa penghianatan terhadap negara, korupsi, penyuapan, tindak pidana berat lainnya atau perbuatan tercela maupun apabila terbukti tidak lagi memenuhi syarat sebagai Presiden dan/atau Wakil Presiden.

Memperhatikan ketentuan tesebut, ada dua kelompok alasan untuk memakzulkan Presiden dan/atau Wakil Presiden, yaitu; 1) alasan pelanggaran hukum, dan 2) alasan tidak lagi memenuhi syarat sebagai Presiden dan/atau Wakil Presiden (incapacity). Ada lima alasan pelanggaran hukum yaitu: a) penghianatan terhadap Negara; b) korupsi; c) penyuapan; d) tindak pidana berat lainnya; dan d) perbuatan tercela. Berikut ini akan diuraikan alasanalasan pemakzulan Presiden dan/atau Wakil Presiden tersebut. ${ }^{7}$

\section{a. Penghianatan Terhadap Negara}

Pengertian penghianatan terhadap negara, dapat ditemukan dalam Pasal 10 UndangUndang Nomor 24 tahun 2003 tentang Mahkamah Konstitusi, yaitu tindak pidana terhadap keamanan negara yang diatur dalam undang-undang. Sehubungan dengan itu, dapat dikemukakan bahwa sebagian besar tindak pidana terhadap keamanan negara diatur dalam Kitab Undang-Undang Hukum Pidana (KUHPidana) dan sebagaian diluar KUHPidana seperti tindak pidana terorisme. ${ }^{8}$

Kejahatan penghianatan terhadap negara dalam KUHPidana mencakup jenis - jenis tindak pidana sebagai berikut: 1) Makar terhadap kepala negara (Pasal 104); 2) Makar untuk memasukkan Indonesia di bawah kekuasaan asing (Pasal 106); 3) Makar untuk menggulingkan pemerintah (pasal 107); 4) Pemberontakan (opstand) (Pasal 108); 5) Permufakatan jahat dan/atau penyertaan untuk melakukan kejahatan yang dimaksud dalam Pasal 104, 106, 107, dan 108 KUHPidana; 6) Mengadakan hubungan dengan negara asing yang bermusuhan dengan Indonesia (Pasal 111); 7) Mengadakan hubungan dengan negara asing dengan tujuan agar negara asing membantu sesuatu penggulingan terhadap pemerintah di Indonesia (Pasal 111 bis); 8) Menyiarkan surat-surat rahasia (Pasal 112-116); 9) Kejahatan-kejahatan mengenai bangunan-bangunan pertahanan negara (Pasal 117-120); 10) Merugikan negara dalam perundingan diplomatik (Pasal 121); 11) Kejahatan yang biasanya dilakukan oleh mata-mata musuh (Pasal 122-125); 12) Menyembunyikan mata-mata musuh (Pasal 126); 13) Menipu dalam hal menjual barang-barang keperluan tentara. ${ }^{9}$

\section{b. Korupsi dan Penyuapan}

Korupsi dan penyuapan dalam hukum pidana Indonesia diatur dalam satu undangundang tersendiri yaitu Undang-Undang Tindak Pidana Korupsi, sehingga segala tindak pidana yang diatur dalam undang-undang tersebut dapat dikualifikasi sebagai tindak pidana korupsi. Tindak pidana korupsi dalam undang-undang ini mencakup tiga kelompok tindak

6 Putra,M.D. (2016). "Proses Hukum pemberhentian Presiden dan/atau Wakil Presiden menurut Undang-Undang Dasar Negara Republik Indonesia Tahun 1945”, Jurnal Ilmiah Fakultas Keguruan dan Ilmu Pendidikan. 18 (2). h. 1-10.

7 Zoelva, H, op. cit., h. 15-16.

8 Ibid., h. 16-17.

9 Ibid., h. 19-20. 
pidana, yaitu:

1) Tindak pidana korupsi yang umum sebagaimana diatur dalam Pasal 2 dan Pasal 3 UU No. 31 Tahun 1999 yang terdiri atas:

a) Perbuatan yang secara melawan hukum memperkaya diri sendiri atau orang lain atau suatu korporasi yang dapat merugikan keuangan atau perekonomian Negara;

b) Perbuatan yang menyalahgunakan kewenangan, kesempatan atau sarana yang ada padanya karena jabatan atau kedudukan dengan tujuan menguntungkan diri sendiri atau orang lain atau korporasi yang dapat merugikan keuangan negara atau perekonomian negara.

2) Tindak pidana korupsi yang sebelumnya merupakan tindak pidana suap yang terkait dengan jabatan pegawai negeri, hakim, advokat, sebagaimana yang diatur dalam kitab Undang-Undang Hukum Pidana (KUHP); jabatan penyelenggara negara, serta pemborong, ahli bangunan serta pengawas pembangunan, yang terkait dengan kepentingan umum dan kepentingan Tentara Nasional Indonesia.

3) Tindak pidana lain yang berkaitan dengan tindak pidana korupsi, yaitu perbuatan yang dilakukan dengan sengaja mencegah, merintangi, atau menggagalkan secara langsung atau tidak langsung penyidikan, penuntutan dan pemeriksaan di pengadilan terhadap tersangka, terdakwa maupun para saksi dalam perkara korupsi, termasuk juga memberikan keterangan yang tidak benar atau tidak mau memberikan keterangan oleh tersangka, saksi, saksi ahli dan petugas bank terkait dengan proses pemeriksaan tindak pidana korupsi. ${ }^{10}$

\section{c. Tindak Pidana Berat Lainnya}

Penjelasan atas istilah "tindak pidana berat lainnya" dapat ditemukan dalam Pasal 10 ayat (3) huruf c Undang-Undang Nomor 24 tahun 2003 tentang Mahkamah Konstitusi bahwa yang dimaksud "tindak pidana berat lainnya" adalah tindak pidana yang diancam dengan pidana penjara 5 (lima) tahun atau lebih. Definisi yang diberikan Undang-Undang Mahkamah Konstitusi mengenai tindak pidana berat lainnya ini tidak jelas mengacu pada alasan atau landasan hukum apa. Sebab istilah tindak pidana berat itu sendiri tidak dikenal dalam doktrin hukum pidana.

Hukum Pidana mengenal pembedaan antara Pelanggaran dan Kejahatan sebagaimana disebut dalam KUHP. Doktrin pidana juga mengenal pembedaan antara ordinary crime dengan extraordinary crime. Namun demikian, definisi yang diberikan Undang-Undang Mahkamah Konstitusi setidaknya memberikan parameter yang jelas atas konsep "tindak pidana berat" yang berarti bahwa Presiden dan/atau Wakil Presiden telah melakukan perbuatan pidana yang diancam dengan pidana penjara 5 (lima) tahun atau lebih. Sehingga bilamana DPR menemukan bahwa Presiden dan/atau Wakil Presiden melakukan suatu perbuatan yang diancam dengan pidana penjara 5 (lima) tahun atau lebih maka, DPR dapat mengajukan tuntutan impeachment ke Mahkamah Kontitusi. ${ }^{11}$

\section{d. Perbuatan Tercela}

Undang-Undang Nomor 24 tahun 2003 tentang Mahkamah Konstitusi Pasal 10 ayat 3 huruf $\mathrm{d}$ menyatakan perbuatan tercela adalah perbutan yang dapat merendahkan martabat Presiden dan/atau Wakil Presiden. Definisi dari konsep perbuatan tercela yang dijabarkan oleh UU MK ini masih mengandung multitafsir. Batasan "perbuatan tercela" yang dimaksud

10 Ibid., h. 25-27

11 Asshiddiqie, J. (2005). Mekanisme Impeachment dan Hukum Acara Mahkamah Konstitusi. Kerjasama Mahkamah Konstitusi Republik Indonesia dengan Konrad Adenauer Stiftung, Jakarta, Laporan Penelitian. 
haruslah perbuatan yang melanggar hukum, karena "perbuatan tercela" sebagaimana ditentukan dalam konstitusi adalah salah satu jenis perbuatan melanggar hukum. Artinya, perbuatan tercela yang tidak melanggar hukum tidak termasuk kategori perbuatan tercela dalam rumusan ini. ${ }^{12}$

Perbuatan tercela dalam ketentuan UUD 1945 ini, tidak hanya terbatas pada segala perbuatan pidana yang ancaman hukumannya dibawah lima tahun sebagaimana diatur dalam hukum pidana, akan tetapi jauh lebih luas dari itu, yaitu termasuk perbutan yang bertentangan dengan norma agama, norma moral, norma adat, serta pelanggaran terhadap konstitusi dan pelanggaran hukum lainnya yang merendahkan martabat Presiden. ${ }^{13}$

\section{e. Tidak Lagi Memenuhi Syarat Sebagai Presiden dan/atau Wakil Presiden}

Undang-Undang Mahkamah Konstitusi merumuskan tidak lagi memenuhi syarat sebagai Presiden dan/atau Wakil Presiden adalah tidak memenuhi syarat sebagaimana ditentukan dalam Pasal 6 Undang-Undang Dasar Negara Republik Indonesia Tahun 1945. Hal ini berarti syarat Presiden adalah sama dengan syarat calon Presiden karena Pasal 6 UUD 1945 mengatur syarat calon Presiden/Wakil Presiden. Jimly Asshiddiqie, ketika menyampaikan pandangan ahli pada saat merumuskan alasan pemakzulan Presiden menyatakan bahwa "tidak memenuhi syarat" adalah in capacited, yaitu apabila Presiden sakit permanen atau hilang ingatan dan lain-lain. ${ }^{14}$

Pasal 6 UUD 1945 secara implisit memuat dua kelompok syarat Presiden, yaitu syarat yang disebutkan secara eksplisit dalam UUD 1945 dan syarat yang diatur lebih lanjud dalam Undang-Undang. Syarat yang secara eksplisit yang diatur dalam UUD adalah: Pertama, warga negara Indonesia sejak kelahirannya dan tidak pernah menerima kewarganegaraan lain karena kehendaknya sendiri. Dengan syarat tersebut tidak memungkinkan untuk menjadi Presiden Republik Indonesia seorang warga negara Indonesia yang kewarganegaraannya diperoleh melalui naturalisasi, karena ia pernah menjadi warga negara lain kecuali status warga negara lain yang diperolehnya bukan atas kehendak sendiri. Dalam hal ini, dapat terjadi apabila seorang yang lahir dari orang tuanya yang berwarga negara Indonesia di suatu negara yang menganut prinsip ius soli (prinsip tempat kelahiran), secara otomatis menjadi warga negara di negara tempat kelahirannya, padahal anak tersebut juga menjadi warga negara Indonesia karena Indonesia menganut prinsip ius sanguinis (karena hubungan darah). ${ }^{15}$ Kedua, tidak pernah menghianati negara. Hal ini berpadanan dengan salah satu syarat untuk memakzulkan Presiden yaitu melakukan perbuatan melanggar hukum berupa penghianatan terhadap negara. Jadi, apabila pada saat menjabat, Presiden terbukti melakukan penghianantan terhadap negara maka terpenuhi alasan memakzulkan Presiden, baik karena tidak lagi memenuhi syarat sebagai Presiden maupun melakukan perbuatan melanggar hukum. Ketiga, syarat mampu secara rohani dan jasmani untuk melaksanakan tugas dan kewajiban sebagai Presiden. UUD 1945, memilih kata "mampu" dan tidak mempergunakan kata "sehat", karena tidak sehat belum tentu tidak mampu. Artinya, hal yang paling penting adalah kemampuan atau kompetensi Presiden secara jasmani dan rohani untuk menjalankan tugas sebagai Presiden yang mungkin saja secara fisik terdapat cacat pada anggota badannya, misalnya kehilangan sebelah tangan atau matanya tidak sehat. Tidak "mampu" disini harus dikaitkan dengan kondisi jasmani maupun rohani Presiden yang tidak

\footnotetext{
12 Zoelva, H, Op. Cit, h. 29-30.

13 Ibid., h. 38.

14 Ibid., h. 38-39.

15 Ibid., h. 39
} 
mampu menjalankan tugas dan kewajibannya sebagai Presiden. ${ }^{16}$ Untuk membuktikan kemampuan jasmani dan rohani Presiden menjalankan tugas sebagai Presiden secara objektif harus dapat dibuktikan dengan keterangan keahlian dari dokter yang independen. ${ }^{17}$

Mengacu pada Pasal 6 Ayat 2 UUD 1945, menyatakan "syarat-syarat untuk menjadi presiden dan wakil presiden diatur lebih lanjud dalam undang-undang". ${ }^{18}$ Dalam Pasal 5 Undang-Undang 42 tahun 2008 tentang Pemilihan Presiden dan Wakil Presiden ada 18 syarat untuk menjadi calon presiden yaitu: 1) bertakwa kepada Tuhan Yang Maha Esa; 2) Warga Negara Indonesia sejak kelahirannya dan tidak pernah menerima kewarganegaraan lain karena kehendaknya sendiri; 3) tidak pernah mengkhianati negara, serta tidak pernah melakukan tindak pidana korupsi dan tindak pidana berat lainnya; 4) mampu secara rohani dan jasmani untuk melaksanakan tugas dan kewajiban sebagai Presiden dan Wakil Presiden; 5) bertempat tinggal di wilayah Negara Kesatuan Republik Indonesia; 6) telah melaporkan kekayaannya kepada instansi yang berwenang memeriksa laporan kekayaan penyelenggara negara; 7) tidak sedang memiliki tanggungan utang secara perseorangan dan/atau secara badan hukum yang menjadi tanggung jawabnya yang merugikan keuangan negara; 8) tidak sedang dinyatakan pailit berdasarkan putusan pengadilan; 9) tidak pernah melakukan perbuatan tercela; 10) terdaftar sebagai Pemilih; 11) memiliki Nomor Pokok Wajib Pajak (NPWP) dan telah melaksanakan kewajiban membayar pajak selama 5 (lima) tahun terakhir yang dibuktikan dengan Surat Pemberitahuan Tahunan Pajak Penghasilan Wajib Pajak Orang Pribadi; 12) belum pernah menjabat sebagai Presiden atau Wakil Presiden selama 2 (dua) kali masa jabatan dalam jabatan yang sama; 13) setia kepada Pancasila sebagai dasar negara, Undang-Undang Dasar Negara Republik Indonesia Tahun 1945, dan cita-cita Proklamasi 17 Agustus 1945 ; 14) tidak pernah dijatuhi pidana penjara berdasarkan putusan pengadilan yang telah mempunyai kekuatan hukum tetap karena melakukan tindak pidana yang diancam dengan pidana penjara 5 (lima) tahun atau lebih; 15) berusia sekurangkurangnya 35 (tiga puluh lima) tahun; 16) berpendidikan paling rendah tamat Sekolah Menengah Atas (SMA), Madrasah Aliyah (MA), Sekolah Menengah Kejuruan (SMK), Madrasah Aliyah Kejuruan (MAK), atau bentuk lain yang sederajat; 17) bukan bekas anggota organisasi terlarang Partai Komunis Indonesia, termasuk organisasi massanya, atau bukan orang yang terlibat langsung dalam G.30.S/PKI; dan 18) memiliki visi, misi, dan program dalam melaksanakan pemerintahan negara Republik Indonesia. Akan tetapi, tidak semua syarat untuk menjadi Presiden yang diatur dalam undang-undang dapat menjadi alasan pemakzulan. Hanya syarat-syarat yang merupakan penjabaran lebih lanjud atau dikaitkan dengan syarat yang ditentukan konstitusi yang dapat menjadi alasan pemakzulan atau syarat incapicited sebagaimana telah diuraikan diatas. ${ }^{19}$

\section{Mekanisme Pemberhentian Presiden dan/atau Wakil Presiden}

Mekanisme pemberhentian Presiden dan/atau Wakil Presiden dalam masa jabatan diatur dalam Pasal 7B UUD NRI Tahun 1945. Untuk memberhentikan seorang Presiden dan/atau Wakil Presiden di Indonesia, harus melalui tahapan yang jelas dan dilakukan oleh 3 (tiga) lembaga negara yakni Dewan Perwakilan Rakyat (DPR), Mahakamh Konstitusi (MK) dan Majelis Permusyawaratan Rakyat (MPR), ketiga lembaga Negara tersebut memiliki kewengan yang berbeda-beda berdasarkan UUD NRI Tahun 1945. Berikut akan diuraikan mekanisme pemberhentian Presiden dan/atau Wakil Presiden.

\footnotetext{
16 Ibid., h. 40

17 Ibid., h. 41

18 Ibid., h. 42

19 Ibid., h. 44.
} 


\section{a. Pengajuan Usul oleh DPR}

Proses awal di DPR, dimulai pelaksanaan fungsi pengawasan berupa penggunaan hak interpelasi, yaitu hak untuk meminta keterangan kepada pemerintah mengenai kebijakan pemerintah yang penting dan strategis serta berdampak luas pada kehidupan berbangsa dan bernegara; dan hak angket, yaitu hak untuk melakukan penyelidikan terhadap kebijakan pemerintah yang penting dan strategis serta berdampak luas terhadap kehidupan bermasyarakat dan bernegara yang diduga bertentangan dengan peraturan perundangundangan. ${ }^{20}$ Dengan adanya hak angket ini secara implisit, UUD 1945 memberikan kewenangan kepada DPR untuk mengadakan penyelidikan terhadap Presiden. ${ }^{21}$ Pelaksanaan hak interpelasi, hak angket dan hak menyatakan pendapat diatur dalam UndangUndang Nomor 17 Tahun 2014 tentang MPR, DPR, DPD dan DPRD. Berikut akan di jelaskan penggunaan hak angket dan hak menyatakan pendapat dalam proses pemberhentian Preisden dan/atau Wakil Presiden.

Hak angket diusulkan paling sedikit 25 (dua puluh lima) orang anggota DPR dan lebih dari satu fraksi, disertai dengan dokumen yang memuat paling sedikit materi kebijakan dan/atau pelaksanaan undang-undang yang akan diselidiki; dan alasan penyelidikan. Usul tersebut menjadi hak angket DPR apabila mendapat persetujan dari rapat peripurna DPR yang dihadiri lebih dari $1 / 2$ (satu perdua) jumlah anggota DPR dan keputusan diambil dengan persetujuan lebih dari 1/2 (satu perdua) jumlah anggota DPR yang hadir. DPR dapat memutuskan menerima atau menolak usul hak angket. Dalam hal DPR menerima usul hak angket, DPR membentuk panitia angket yang keanggotaannya terdiri atas semua unsur fraksi DPR. Sebaliknya dalam hal DPR menolak usul hak angket, usul tersebut tidak dapat diajukan kembali. Panitia angket dalam melakukan penyelidikan selain meminta keterangan dari pemerintah, dapat meminta keterangan dari saksi, pakar, organisasi profesi, dan/atau pihak terkait lainnya. Panitia angket dalam melaksanakan tugasnya dapat memanggil warga Negara Indonesia dan atau orang asing yang bertempat tinggal di Indonesia untuk memberikan keterangan. Panitia angket melaporkan pelaksanaan tugasnya kepada rapat paripurna DPR paling lama 60 (enam puluh) hari sejak dibentuknya panitia angket. Setelah itu diadakan rapat paripurna DPR mengambil keputusan terhadap laporan panitia angket. ${ }^{22}$

Apabila rapat paripurna DPR memutuskan bahwa pelaksanaan suatu undang-undang dan/atau kebijakan pemerintah berkaitan dengan hal penting, strategis, dan berdampak luas pada kehidupan bermasyarakat, berbangsa dan bernegara bertentangan dengan ketentuan peraturan perundang-undangan, DPR dapat menggunakan hak menyatakan pendapat. Hak menyatakan pendapat diusulkan paling sedikit 25 (dua puluh lima) orang anggota DPR, disertai dengan dokumen-dokumen yang dipersyaratkan menurut undang-undang. Usul menjadi hak menyatakan pendapat DPR apabila mendapat persetujuan dari rapat paripurna DPR yang dihadiri paling sedikit $2 / 3$ (dua per tiga) dari jumlah anggota DPR dan keputusan diambil dengan persetujuan paling sedikit $2 / 3$ (dua per tiga) jumlah anggota DPR yang hadir. DPR memutuskan menerima atau menolak usul hak menyatakan pendapat. Dalam hal DPR menerima usul hak menyatakan pendapat, DPR membentuk panitia khusus yang terdiri atas semua unsur fraksi DPR dengan keputusan DPR. Panitia khusus melaporkan pelaksanaan tugasnya kepada rapat paripurna DPR paling lama 60 (enam puluh) hari sejak dibentuk. Rapat paripurna mengambil keputusan terhadap laporan panitia khusus, dalam hal rapat

20 Isra, S. (2007) "Prosedur Konstitusional Pemakzulan Presiden ", makalah disampaikan dalam Seminar Nasional, Teknik Konstitusional Impeachment Presiden, Jakarta. Sebagaimana dikutip oleh Gunawan, W.A. (2008). "Pemakzulan (Impeachment) Presiden dalam Prespektif Hukum Tata Negara", Jurnai Hukum dan Pembangunan, 38 (3): 416-438 DOI : http://dx.doi.org/10.21143/jhp.vol38.no3.178, h.432.

21 Zoelva, H, Op. Cit. h. 101.

22 Republik Indonesia. Undang-Undang Nomor 17 Tahun 2014. Pasal 206 
paripurna DPR memutuskan menerima laporan panitia khusus yang menyatakan bahwa Presiden dan/atau Wakil Presiden melakukan pelenggaran hukum berupa penghianatan terhadap negara, korupsi, penyuapan, tindak pidana berat lainnya, atau perbuatan tercela, ataupun tidak lagi memenuhi syarat sebagai Presiden dan/atau Wakil Presiden, DPR menyampaikan keputusan tentang hak menyatakan pendapat kepada Mahkamah Konstitusi. Keputusan DPR mengenai usul menyatakan pendapat kepada Mahkamah Konstitusi juga disampaikan kepada Presiden. ${ }^{23}$

\section{b. Pemeriksaan di Mahkamah Konstitusi}

UUD 1945 dan Undang-Undang Mahkamah Konstitusi tidak mengatur secara rinci mengenai proses pemeriksaan atas pendapat DPR di Mahkamah Konstitusi. ${ }^{24}$ UndangUndang Nomor 24 tahun 2003 tentang Mahkamah Konstitusi hanya mengatur mekanisme pengajuan permohonan yaitu diajukan oleh DPR selaku Pemohon. DPR harus mengajukan permohonan secara tertulis dan menguraikan secara jelas mengenai dugaan pelanggaran hukum yang dilakukan oleh Presiden kepada Mahkamah Konstitusi dan melampirkan putusan dan proses pengambilan putusan di DPR, risalah dan atau berita acara rapat DPR disertai dengan bukti mengenai dugaan pelanggaran yang dilakukan oleh Presiden. UndangUndang Mahkamah Konstitusi juga mengatur batas waktu penyelesaian permohonan yang harus diputus oleh Mahkamah Konstitusi dalam waktu 90 (sembilan puluh hari) setelah permohonan dicatat dalam buku registrasi perkara konstitusi. Dalam melakukan pemeriksaan atas permohonan DPR, Mahkamah Konstitusi diwajibkan untuk memanggil Presiden sebagai pihak dalam perkara untuk memberikan keterangan atau meminta Presiden untuk memberikan keterangan tertulis. Dalam hal ini, Presiden dapat didampingi atau diwakili oleh kuasanya. ${ }^{25}$

Bila memperhatikan ketentuan hukum acara yang diatur dalam Undang-Undang Mahkamah Konstitusi adalah terbuka kemungkinan bagi Mahkamah Konstitusi untuk memeriksa kembali dan menilai bukti-bukti yang diajukan dan dapat memanggil saksi-saksi. Dengan demikian bukti-bukti yang diajukan oleh DPR dapat dinilai dan diuji kembali dan Mahkamah Konstitusi dapat memanggil kembali saksi-saksi yang pernah dipanggil di DPR serta memanggil saksi-saksi yang baru. Dengan mempergunakan ketentuan Pasal 86 UU Mahkamah Konstitusi, maka Mahkamah Konstitusi dapat membuat hukum acara tambahan sebagai pengaturan lebih lanjut untuk kelancaran pelaksanaan tugas dan wewenangnya. ${ }^{26}$

Persidangan di Makamah Konstitusi merupakan pengadilan untuk menjawab dua pertanyaan paling mendasar tentang fakta dan hukum yaitu apakah benar secara hukum dan konstitusi Presiden telah melakukan tindakan yang menjadi alasan usulan pemakzulan oleh DPR, dan apakah proses pengambilan keputusan di DPR telah sesuai dengan hukum dan konstitusi. ${ }^{27}$ Memperhatikan proses pemeriksaan pendapat DPR di Mahkamah Konstitusi dan ketentuan UUD 1945 yang menentukan bahwa Mahkamah Konstitusi "memeriksa, mengadili dan memutus" dapatlah disimpulkan bahwa sesungguhnya proses pemeriksaan pendapat DPR di Mahkamah Konstitusi adalah sebuah proses peradilan yang tidak terbatas pada pemeriksaan dokumen semata-mata. Karena itu, pemeriksaan pendapat DPR itu dapat dilakukan seperti pemeriksaan dalam perkara pidana dalam peradilan pidana. Hanya saja

23 Republik Indonesia. Undang-Undang Nomor 17 Tahun 2014. Pasal 214

24 Zoelva, H, Op. Cit. h. 107.

25 Zoelva, H, Op. Cit. h. 108-109

26 Gunawan, W.A. (2008). "Pemakzulan (Impeachment) Presiden dalam Prespektif Hukum Tata Negara”, Jurnal Hukum dan Pembangunan. $38 \quad$ (3): $416-488$ DOI: http://dx.doi.org/10.21143/jhp.vol38.no3.178, h. 434.

27 Zoelva, H, Op. Cit. h. 110. 
posisi Presiden bukanlah seperti posisi terdakwa dalam perkara pidana, akan tetapi sebagai pihak dalam perkara yang memiliki posisinya sejajar dengan pemohon yaitu DPR yang bertindak seperti "penuntut" dalam perkara pidana. Dengan proses seperti ini, Mahkamah Konstitusi dapat secara obyektif dan secara mendalam memeriksa dan mengadili perkara yang diajukan oleh DPR, dan terhindar dari kepentingan dan pandangan politik yang dapat saja subyektif dari DPR. ${ }^{28}$

Pasal 83 Undang-Undang Nomor 24 Tahun 2003 menentukan amar putusan Mahkamah Konstitusi atas pendapat DPR tersebut sekurang-kurangnya terdiri dari tiga kemungkinan. Pertama, amar putusan MK menyatakan bahwa permohonan tidak dapat diterima apabila permohonan tidak memenuhi syarat. Kedua, amar putusan MK membenarkan pendapat DPR apabila Presiden dan/atau Wakil Presiden terbukti melakukan tindakan yang dituduhkan. Ketiga, amar putusan MK menyatakan bahwa permohonan ditolak apabila Presiden dan/atau Wakil Presiden tidak terbukti melakukan tindakan yang dituduhkan.

Dalam hal putusan Mahkamah Konstitusi menyatakan bahwa permohonan ditolak apabila Presiden dan/atau Wakil Presiden tidak terbukti melakukan tindakan yang dituduhkan, proses pemakzulan presiden berhenti dan tidak dapat dilanjutkan ke MPR. Sebaliknya, apabila Mahkamah Konstitusi memutuskan mengabulkan permohonan dan membenarkan pendapat DPR, maka proses pemakzulan dilanjutkan ke MPR. ${ }^{29}$

\section{c. Sidang Majelis Permusyawaratan Rakyat}

Pasal 7B ayat (5) UUD NRI tahun 1945 menyatakan apabila Mahkamah Konstitusi memutuskan bahwa Presiden dan/atau Wakil Presiden terbukti melakukan pelanggaran hukum berupa penghianatan terhadap negara, korupsi, penyuapan tindak pidana berat lainnya, atau perbuatan tercela; dan/atau terbukti bahwa Presiden dan/atau Wakil Presiden tidak lagi memenuhi syarat sebagai Presiden dan/atau Wakil Presiden, Dewan Perwakilan Rakyat menyelenggarakan sidang paripurna untuk meneruskan usul pemberhentian Presiden dan/atau Wakil Presiden kepada Majelis Permusyawaratan Rakyat. MPR setelah menerima usul DPR wajib menyelenggarakan sidang paripurna untuk memutuskan usul DPR mengenai pemberhentian Presiden dan/atau Wakil Presiden pada masa jabatannya dalam waktu selambat-lambatnya 30 (tiga puluh) hari setelah MPR menerima usulan tersebut. Selanjutnya pimpinan MPR mengundang Presiden dan/atau Wakil Presiden untuk menyampaikan penjelasan yang berkaitan dengan usulan pemberhentiannya dalam sidang paripurna MPR. Presiden dan/atau Wakil Presiden dan/atau Wakil Presiden wajib hadir untuk memberikan penjelasan atas usul pemberhentiannya. Apabila Presiden dan/atau Wakil Presiden tidak hadir untuk menyampaikan penjelasan, MPR tetap mengambil putusan terhadap usul pemberhentian Presiden dan/atau Wakil Presiden. ${ }^{30}$

Pengambilan Putusan terhadap usul pemberhentian Presiden dan/atau Wakil Presiden yang diajukan DPR setelah adanya putusan MK dilaksanakan melalui mekanisme pengambilan suara terbanyak. ${ }^{31}$ Keputusan MPR atas usul pemberhentian Presiden dan/atau Wakil Presiden harus diambil dalam rapat paripurna Majelis Permusyawaratan Rakyat yang dihadiri sekurang-kurangnya 3/4 (tiga perempat) dari jumlah anggota dan disetujui oleh sekurang-kurangnya $2 / 3$ (dua pertiga) dari jumlah anggota yang hadir, setelah Presiden dan/atau Wakil Presiden diberi kesempatan menyampaikan penjelasan dalam rapat paripurna

\footnotetext{
28 Ibid. h. 110-111.

${ }^{29}$ Ibid. h. 112.

30 Republik Indonesia. Undang-Undang Nomor 17 Tahun 2014. Pasal 38 ayat (1) dan (2).

31 Asshiddiqie, J. Op. Cit.
} 
Majelis Permusyawaratan Rakyat. ${ }^{32}$ Dalam hal MPR memutusakan memberhentikan Presiden dan/atau Wakil Presiden atas usul DPR, Presiden dan/atau Wakil Presiden berhenti dari jabatannya. Dalam hal MPR memutuskan tidak memberhentikan Presiden dan/atau Wakil Presiden atas usul DPR, Presiden dan/atau Wakil Presiden melaksanakan tugas dan kewajibannya sampai berakhir masa jabatannya. Putusan MPR dalam hal memutuskan memberhentikan ataupun tidak memberhentikan Presiden dan/atau Wakil Presiden ditetapkan dengan Ketetapan MPR. ${ }^{33}$ Apabila Presiden dan/atau Wakil Presiden mengundurkan diri sebelum diambil putusan MPR, maka sidang paripurna tidak dilanjutkan. ${ }^{34}$

\section{Politik Hukum Pemberhentian Presiden dan/atau Wakil Presiden dalam Prespektif Negara Hukum dan Demokrasi}

Politik dan hukum adalah dua hal yang sulit dipisahkan atau tidak mungkin dipisahkan, karena kedua-duanya mempunyai hubungan yang sedemikian eratnya. Bahkan karena eratnya hubungan keduanya, sulit pula untuk menentukan mana yang paling berpengaruh apakah politik berpengaruh terhadap hukum, dan sebaliknya apakah hukum yang berpengaruh terhadap politik. Persoalan tersebut kiranya mampu dijawab dalam ranah politik hukum. Sebagaimana dikemukakan oleh Padmo Wahjono, Politik Hukum adalah kebijakan dasar yang menentukan arah, bentuk maupun isi hukum yang akan dibentuk. ${ }^{35}$ Mahfud MD, mendefinisikan politik hukum adalah legal policy atau garis (kebijakan) resmi tentang hukum yang akan diberlakukan baik dengan pembuatan hukum baru maupun dengan penggantian hukum lama, dalam rangka mencapai tujuan negara. ${ }^{36}$

Berdasarkan pengalaman sejarah ketatanegaraan Indonesia tercatat terdapat 2 (dua) Presiden yang pernah diberhentikan oleh MPR sebelum berakhir masa jabatannya. Pertama, Presiden Soekarno diberhentikan dari jabatan Presiden melaui Ketetapan MPRS Nomor XXXIII/MPRS/1967 tentang Pencabutan Kekuasaan Pemerintahan Negara karena pertanggungjawabannya ditolak oleh Majelis Permusyawaratan Rakyat Sementara (MPRS) berkaitan dengan peristiwa pemberontakan G-30 S/PKI yang merupakan tindak pidana makar. ${ }^{37}$ Kedua, Presiden Abdul Rahman Wahid diberhentikan oleh MPR melalui ketetapan MPR Nomor II/MPR/2001 tentang Pertanggungjawaban Presiden Republik Indonesia K.H Abdul Rahman Wahid, karena tidak hadir dan menolak memberikan pertanggungjawaban dalam sidang istimewa MPR tahun 2001, dinilai terlibat dalam kasus penyelewengan dana bulog (Bulogate) dan dana bantuan dari Brunei Darusalam (Bruneigate) serta menerbitkan Maklumat Presiden RI tanggal 23 Juli tahun 2001.

Pemberhentian Presiden dalam masa jabatannya sebelum perubahan UUD NRI Tahun 1945, lebih didasarkan pada pertimbangan politik dengan alasan yang sumir dan cenderung disebabkan alasan politis yaitu adanya pertentangan antara eksekutif dan legislatif. Pemberhentian Presiden hanya melibatkan lembaga DPR dan MPR, tanpa melibatkan lembaga peradilan untuk membuktikan dugaan pelanggaran yang dituduhkan terhadap Presiden. Seperti halnya tuduhan DPR terhadap mantan Presiden Soekarno diduga terlibat dalam G-30 S/PKI dan tuduhan terhadap mantan Presiden Abdul Rahman Wahid diduga terlibat dalam kasus penyelewengan dana bulog (Bulogate) dan dana bantuan dari Brunei Darusalam (Bruneigate), akan tetapi tuduhan-tuduhan tersebut secara hukum tidak dapat

\footnotetext{
32 Undang-Undang Dasar Negara Republik Indonesia Tahun 1945. Pasal 7B ayat (7).

33 Republik Indonesia. Undang-Undang Nomor 17 tahun 2014. Pasal 39 ayat (1), (2), dan (3).

34 Republik Indonesia. Undang-Undang Nomor 17 tahun 2014. Pasal 40.

35 Wahjono, P. (1886). Indonesia Berdasar Atas Hukum. Jakarta: Ghalilia Indonesia, h. 160

36 Mahfud, MD. (2012). Politik Hukum di Indonesia, Jakarta: RajaGrafindo Persada, h. 1.

37 Zoelva, H. Op. Cit, h. 6.
} 
dibuktikan kebenarannya. Praktik ketatanegaraan tersebut disamping bertentangan dengan sistem Presidensial juga membuka peluang terjadinya ketegangan dan krisis politik dan kenegaraan selama masa jabatan Presiden.

Perubahan UUD NRI Tahun 1945, telah mengubah sistem ketatanegaraan Indonesia secara mendasar terutama terkait dengan pengangkatan dan pemberhentian Presiden dan/atau Wakil Presiden. Pertama, MPR tidak lagi ditempatkan sebagai lembaga tertinggi negara yang sepenuhnya melaksanakan kedaulatan rakyat. Kedua, memberikan penguatan dan mempertegas sistem presidensial yang dianut yaitu dengan menentukan bahwa Presiden dan Wakil Presiden dipilih langsung oleh rakyat. Perubahan ini membawa dampak yuridis yang sangat luas dalam proses ketatanegaraan Indonesia. Presiden tidak lagi tunduk dan bertanggung jawab kepada MPR untuk melaksanakan Garis-Garis Besar Haluan Negara, sebagaimana diatur dalam UUD NRI Tahun 1945 sebelum perubahan. Presiden tidak lagi dapat diberhentikan oleh MPR karena alasan Presiden melanggar haluan negara. Ketentuan tentang alasan dan mekanisme pemberhentian Presiden dan/atau Wakil Presiden dalam masa jabatannya telah diatur secara limitatif pada Pasal 7A dan Pasal 7B UUD NRI Tahun 1945.

Menurut ketentuan Pasal 7A UUD NRI Tahun 1945 Presiden dan/atau Wakil Presiden dapat diberhentikan dalam masa jabatannya oleh Majelis Permusyawaratan Rakyat atas usul Dewan Perwakilan Rakyat baik apabila terbukti telah melakukan pelanggaran hukum berupa penghianatan terhadap negara, korupsi, penyuapan, tindak pidana berat lainnya atau perbuatan tercela maupun apabila terbukti tidak lagi memenuhi syarat sebagai Presiden dan/atau Wakil Presiden. Sedangkan mekanisme pemberhentian Presiden dan/atau Wakil Presiden juga diatur dalam Pasal 7B UUD NRI Tahun 1945, yang mana dalam ketentuan tersebut pemberhentian Presiden dan/atau Wakil Presiden dilakukan oleh 3 (tiga) lembaga negara, yaitu DPR, MK, dan MPR yang masing-masing memiliki kewenangan yang berbeda. Proses pemberhentian Presiden dan/atau Wakil Presiden dalam masa jabatannya dilakukan melalui 3 (tiga) tahapan. Pertama, pernyataan pendapat dari DPR bahwa Presiden dan/atau Wakil Presiden telah melakukan pelanggaran hukum sebagaimana dimksud dalam Pasal 7B ayat (1) UUD NRI Tahun 1945. Kedua, adanya putusan Mahkamah Konstitusi bahwa pendapat DPR tersebut terbukti benar. Ketiga, pemberhentian oleh MPR jika MPR berketetapan bahwa pelanggaran yang dilakukan oleh Presiden dan/atau Wakil Presiden itu layak dijatuhi hukuman pemberhentian. Ketentuan tersebut merupakan salah satu pelaksanaan prinsip saling mengawasi dan saling mengimbangi (checks and balances) antarlembaga negara khususnya DPR, MK dan MPR.

Berdasarkan muatan berbagai konstitusi di banyak negara, pemberhentian Presiden dan/atau Wakil Presiden dapat dilakukan melalui proses dan keputusan politik (impeachment) atau melalui proses dan putusan hakim di pengadilan (forum previlegiatum). Pemberhentian melalui impeachment dimaksudkan bahwa pemberhentian Presiden dan/atau Wakil Presiden dilakukan dengan mekanisme dan syarat-syarat tertentu oleh lembaga perwakilan rakyat. Sedangkan pemberhentian melalui forum previlegiatum dimaksudkan bahwa pemberhentian Presiden dan/atau Wakil Presiden melalui proses hukum dan putusan pengadilan. ${ }^{38}$ Mahfud M.D, berdasarkan penelitiannya terhadap berbagai konstitusi yang ada di dunia berpendapat bahwa secara teoritis pemberhentian Presiden dan/atau Wakil Presiden menurut UUD NRI 1945 menerapkan model campuran antara impeachment dan forum previlegiatum. ${ }^{39}$ Pemberhentian Presiden dan/atau Wakil Presiden di Indonesia dilakukan melalui proses

38 Sekretaris Jenderal MPR RI, Loc. Cit., h. 91-92.

39 Mahfud, M.D. (2011). Perdebatan Hukum Tata Negara. Jakarta: Rajawali Pers, h. 143. Sebagaimana dikutip oleh Miru, I.R. 2017. "Pemberhentian Presiden dan/atau Wakil Presiden dalam Kaitannya dengan Upaya Mewujudkan Negara Hukum Demokratis Indonesia”. Mimbar Keadilan Jurnal Ilmu Hukum, 66-79 DOI: https://doi.org/10.30996/mk.v0i0.2200,h. 77. 
politik dan proses hukum. Proses politik yaitu dengan adanya pendapat DPR dan keputusan pemberhentian MPR sedangkan proses hukum yaitu dengan cara Mahkamah Konstitusi memeriksa, mengadili, dan memutus pendapat Dewan Perwakilan Rakyat. Pemberhentian Presiden dan/atau Wakil Presiden dilakukan oleh MPR jika proses hukum (forum previlegiantum) telah ditempuh melalui Mahkamah Konstitusi, yang sebelumnya harus didahului dengan pernyataan pendapat oleh DPR bahwa Presiden dan/atau Wakil Presiden telah melakukan pelanggaran hukum. ${ }^{40}$

Keputusan MPR dalam menjalankan fungsinya yakni, memberhentikan Presiden dan/atau Wakil Presiden dalam masa jabatan aktifnya adalah putusan non yuridis atau kita kenal dengan istilah putusan politik (politieke beslissing), bukan putusan peradilan (judicieele vonnis), kerena kewenangan konstitusionalnya dimiliki oleh MPR, bukan kewenangan lembaga peradilan (rechspraak). ${ }^{41}$ Manakala rapat paripurna MPR kelak memakzulkan Presiden dan/atau Wakil Presiden maka keputusannya sebatas remofal from the office, yakni memakzulkannya dari jabatan Presiden dan/atau Wakil Presiden. Keputusan MPR tidak memuat sanksi pidana dan semacamnya. Begitupun sebaliknya, MPR tidak harus memberhentikan Presiden dan/atau Wakil Presiden meskipun putusan Mahkamah Konstitusi membenarkan pendapat DPR bahwa Presiden dan/atau Wakil Presiden telah melakukan pelanggaran hukum tertentu menurut konstitusi. ${ }^{42}$ Manakala rapat paripurna MPR menerima baik penjelasan Presiden dan/atau Wakil Presiden sebagaimana dimaksud pada Pasal 7B ayat (7) UUD NRI Tahun 1945, niscaya MPR tidak memakzulkan Presiden dan/atau Wakil Presiden. ${ }^{43}$ Proses yang terjadi di MPR sesungguhnya adalah pengambilan keputusan politik untuk menentukan apakah Presiden dan/atau Wakil Presiden layak untuk dimakzulkan atau tidak dimakzulkan. ${ }^{44}$ Putusan MPR dalam pemberhentian Presiden dan/atau Wakil Presiden sangat bergantung pada suara mayoritas majelis yang mendukung layak atau tidaknya Presiden dan/atau Wakil Presiden dimakzulkan.

Keputusan Majelis Permusyawaratan Rakyat atas usul pemberhentian Presiden dan/atau Wakil Presiden harus diambil dalam rapat paripurna Majelis Permusyawaratan Rakyat yang dihadiri oleh sekurang-kurangnya 3/4 dari jumlah anggota dan disetujui oleh sekurang-kurangnya 2/3 dari jumlah anggota yang hadir, setelah Presiden dan/atau Wakil Presiden diberi kesempatan menyampaikan penjelasan dalam rapat paripurna Majelis Permusyawaratan Rakyat. ${ }^{45}$ Disinilah kemudian tejadi tarik - menarik dalam pengambilan keputusan, jika Presiden dan/atau Wakil Presiden mendapat dukungan politik yang lemah di lembaga perwakilan, maka kemungkinan untuk memberhentikan Presiden dan/atau Wakil Presiden akan lebih mudah. Sebaliknya, jika Presiden dan/atau Wakil Presiden mendapat dukungan politik yang kuat di lembaga perwakilan, maka kemungkinan untuk diberhentikan akan sulit. Perimbangan kekuatan politk tersebut dapat dilihat dari jumlah partai politik yang mengusung Presiden dan/atau Wakil Presiden dan partai koalisi yang mendukung pemerintah. Menurut penulis, untuk menentukan keputusan pemberhentian Presiden dan/atau Wakil Presiden dalam masa jabatannya, dukungan politik dalam rapat paripurna lebih berpengaruh dibandingkan dengan putusan hukum yang menunjukan bahwa Presiden dan/atau Wakil Presiden telah nyata melakukan pelanggaran hukum sebagaimana yang

40 Sekretaris Jenderal MPR RI, Loc. Cit., h. 91-92.

41 Marzuki, L, (2006). Berjalan Jalan di Ranah Hukum. Jakarta: Sekretariat Jenderal Mahkamah Konstitusi dan Kepaniteraan Mahkamah Konstitusi, h. 44.

42 Sekretaris Jenderal MPR RI, Loc. Cit., h. 92-93.

43 Marzuki, L. (2006). "Pemakzulan Presiden/Wakil Presiden Menurut Undang-Undang Dasar 1945". Jurnal Konstitusi, 7 (1) : 15-28 DOI : https://doi.org/10.31078/jk\%25x, h. 26.

44 Zoelva, H. Op. Cit., h.112.

45 Nadir. (2012). "Dilematika Putusan Mahkamah Konstitusi vs Kekuatan Politik dalam Impeachment Presiden”. Jurnal Konstitusi, 9 (2) : 334-356 DOI : https://doi.org/10.31078/jk\%25x, h. 346. 
dimaksud dalam UUD NRI Tahun 1945. Oleh sebap itu diperlukan sikap kenegarawanan dikala pengambilan keputusan pemakzulan, tidak boleh didasarkan pada dendam kesumat politik. Apapun keputusannya, harus senantiasa didasarkan belaka pada kepentingan dan kemaslahatan rakyat banyak selaku pemegang kedaulatan di negeri ini. ${ }^{46}$ Dengan demikian, bahwa proses pemkzulan Presiden dan/atau Wakil Presiden tidaklah mudah, bahkan dari sudut pandang politik proses pemakzulan Presiden didesain menjadi sangat sulit karena harus mendapat persetujuan mayoritas mutlak. ${ }^{47}$

Tahapan-tahapan proses tersebut membuktikan bahwa dalam memberhentikan Presiden dan/atau Wakil Presiden yang masih dalam jabatannya, UUD NRI Tahun 1945 berpijak pada paham negara demokrasi seperti diatur dalam Pasal 1 ayat (2) UUD NRI Tahun 1945 dan berpijak pada paham negara hukum seperti diatur dalam Pasal 1 ayat (3) UUD NRI Tahun 1945. Penerapan paham demokrasi dilakukan melalui pernyataan pendapat lebih dahulu oleh DPR dan pemberhentian oleh MPR, yang merupakan lembaga perwakilan rakyat dengan fungsi yang berbeda. Penerapan paham negara hukum dilakukan melalui forum previlegiatum, yaitu dengan pemeriksaan pengadilan dan putusan Mahkamah Konstitusi sebagai pemegang kekuasaan kehakiman sebelum MPR benar-benar memberhentikan Presiden dan/atau Wakil Presiden, ${ }^{48}$ dalam hal MPR tidak memberhentikan Presiden dan/atau Wakil Presiden, bukan berarti MPR menganulir putusan Mahkamah Konstitusi yang membenarkan pendapat DPR, karena MPR tidak menilai putusan Mahkamah Konstitusi. MPR hanya memutuskan apakah dengan pelanggaran yang dibuktikan dan dengan pertimbangan kemanfaatan bagi rakyat dan negara, Presiden dan/atau Wakil Presiden harus diberhentikan atau tidak perlu diberhentikan. Setelah selesai pemakzulan, Presiden dan/atau Wakil Presiden dapat saja dituntut secara pidana melalui peradilan pidana biasa manakala ada dugaan tindak pidana biasa yang dilakukan oleh Presiden dan/atau Wakil Presiden. ${ }^{49}$ Ataupun jika Presiden dan/atau Wakil Presiden tidak diberhentikan oleh MPR, menurut penulis Presiden dan/atau Wakil Presiden tersebut dapat menjalani proses hukum setelah berakhir masa jabatannya

\section{P E N U T U P}

Berdasarkan pembahasan di atas, maka dapat disimpulkan bahwa setelah perubahan UUD NRI Tahun 1945 alasan untuk memberhentikan Presiden dan/atau Wakil Presiden telah ditentukan secara limitatif, bahwa Presiden dan/atau Wakil Presiden hanya dapat diberhentikan dalam masa jabatannya oleh MPR apabila Presiden dan/atau Wakil Presiden telah terbukti melakukan pelanggaran hukum, khususnya pelanggaran hukum pidana. Walaupun terdapat alasan perbuatan tercela sebagai alasan pemberhentian Presiden dan/atau Wakil Presiden yang dinilai dapat menimbulkan multitafsir, akan tetapi perbuatan tercela yang dimaksud tersebut adalah perbuatan tercela yang dapat merendahkan martabat seorang Presiden dan/atau Wakil Presiden sehingga Presiden dan/atau Wakil Presiden kehilangan legitimasi untuk memimpin negara. Pemberhentian Presiden dan/atau Wakil Presiden di Indonesia berpijak pada paham negara demokrasi dan paham negara hukum. Penerapan paham negara demokrasi dilakukan melalui pernyataan pendapat lebih dahulu oleh DPR dan pemberhentian oleh MPR, yang merupakan lembaga perwakilan rakyat dengan fungsi yang berbeda. Penerapan paham negara hukum dilakukan melalui forum previlegiatum (peradilan

46 Laica Marzuki (2016) "Pemakzulan Presiden/Wakil Presiden Menurut Undang-Undang Dasar 1945”, Jurnal Konstitusi, 7 (1) : 15-28 DOI: https://doi.org/10.31078/jk\%25x, h. 27.

47 Kristiyanto, E.N. (2013). "Pemakzulan Presiden Republik Indonesia Pasca Amandemen UUD 1945 ”. Jurnal RechtsVinding, 2 (3) : 331-342 h. 340.

48 Sekretaris Jenderal MPR RI, Op.Cit., Hal. 93

49 Zoelva, H. Op.Cit, h. 113 
khusus), yaitu dengan pemeriksaan pengadilan dan putusan Mahkamah Konstitusi sebagai pemegang kekuasaan kehakiman sebelum MPR benar-benar memberhentikan Presiden dan/atau Wakil Presiden. Politik hukum pemberhentian Presiden dan/atau Wakil Presiden adalah UUD NRI Tahun 1945 telah mempersulit pemberhentian Presiden dan/atau Wakil Presiden dalam masa jabatannya baik dari segi alasan dan mekanisme pemberhentian. Pilihan hukum tersebut dimaksudkan untuk memperkuat sistem presidensial yang menganut prinsip fix term jabatan Presiden dan/atau Wakil Presiden dan untuk menjamin penyelenggaraan pemerintahan negara yang stabil. MPR dalam menjalankan fungsinya dapat memberhentikan atupun menolak untuk memberhentikan Presiden dan/atau Wakil Presiden.

\section{DAFTAR PUSTAKA}

\section{Jurnal}

[1] Miru, I.R. (2017). Pemberhentian Presiden dan/atau Wakil Presiden dalam Kaitannya dengan Upaya Mewujudkan Negara Hukum Demokratis Indonesia. Mimbar Keadilan Jurnal Ilmu Hukum, 66-79 DOI: https://doi.org/10.30996/mk.v0i0.2200,h. 77

[2] Mulyanti, D. (2018). Mekanisme Pemberhentian Presiden dalam Sistem Pemerintahan Presidensial di Indonesia (Tinjauan Perbandingan Hukum di Negara Amerika Serikat, Filipina dan Sudan). Jurnal Ilmiah Galuh Justisi, 6 (2).

[3] Kristiyanto, E. N. (2013). Pemakzulan Presiden Republik Indonesia Pasca Amandemen UUD 1945. Jurnal RechtsVinding, 2 (3).

[4] Sulistiani, A. (2018). Impeachment Presiden (Studi Perbandingan Ketatanegaraan Indonesia dan Ketatanegaraan islan). Jurnal Al-Dastur, 1 (1).

[5] Gunawan, W. A. (2008). Pemakzulan (Impeachment) Presiden dalam Prespektif Hukum Tata Negara, Jurnal Hukum dan Pembangunan, Tahun ke-38 Nomor 3.

[6] Marzuki, L. (2010). Pemakzulan Presiden/Wakil Presiden Menurut Undang-Undang Dasar 1945. Jurnal Konstitusi, 7 (1).

[7] Nadir. (2012). Dilematika Putusan Mahkamah Konstitusi vs Kekuatan Politik dalam Impeachment Presiden. Jurnal Konstitusi, 9 (2).

\section{Buku}

[8] Marzuki, Laica. (2006). Berjalan Jalan di Ranah Hukum. Jakarta: Sekretariat Jenderal Mahkamah Konstitusi dan Kepaniteraan Mahkamah Konstitusi.

[9] Mahfud, M.D. (2011). Perdebatan Hukum Tata Negara. Jakarta: Rajawali Pers.

[10] Mahfud, M.D. (2012). Politik Hukum di Indonesia. Jakarta: RajaGrafindo Persada.

[11] Wahjono, P, (1986). Indonesia Berdasar Atas Hukum, Jakarta: Ghalilia Indonesia.

[12] Nazriyah, R. (2007). MPR RI Kajian terhadap Produk Hukum dan Prospek di Masa Depan. Cetakan Kedua, Yogyakarta: FH UII Press.

[13] Sekretaris Jenderal MPR RI. (2011). Panduan Pemasyarakatan Undang-Undang Dasar Negara Republik Indonesia Tahun 1945 dan Ketetapan Majelis Permusyawaratan Rakyat. Jakarta: Sekretariat Jenderal MPR RI.

[14] Zoelva, H. (2014). Impeachment Presiden Alasan Tindak Pidana Pemberhentian Presiden Menurut UUD 1945. Cetakan Kedua (Edisi Revisi). Jakarta: Konstitusi Press 


\section{Skripsi, Tesis, Disertasi dan Lain-Lain}

[15] Asshiddiqie, J. (2005). Mekanisme Impeachment dan Hukum Acara Mahkamah Konstitusi" Kerjasama Mahkamah Konstitusi Republik Indonesia dengan Konrad Adenauer Stiftung, Laporan Penelitian, Jakarta. 